University of Wollongong

Research Online

Faculty of Business - Papers (Archive)

Faculty of Business and Law

2014

The effect of financial status on earnings quality of Chinese-listed firms

Feng Li

University of Wollongong, fengli@uow.edu.au

Indra Abeysekera

University of Wollongong, indraa@uow.edu.au

Shiguang Ma

University of Wollongong, shiguang@uow.edu.au

Follow this and additional works at: https://ro.uow.edu.au/buspapers

Part of the Business Commons

Research Online is the open access institutional repository for the University of Wollongong. For further information contact the UOW Library: research-pubs@uow.edu.au 


\title{
The effect of financial status on earnings quality of Chinese-listed firms
}

\begin{abstract}
This article investigates the relation between accounting-based earnings quality attributes and the financial status of Chinese companies listed in Shanghai and Shenzhen stock exchanges from 2005 to 2007 by classifying them as either "healthy" or "bankrupt" firms. The authors find that accruals quality, earnings predictability, and earnings smoothness are significantly different between healthy and bankrupt firms, but not earnings persistence. Additional analysis undertaken indicates that firm categories (healthy, financially distressed, and bankrupt) based on financial status does not indicate distinct differences in earnings quality attributes.
\end{abstract}

Keywords

financial, quality, chinese, earnings, status, effect, listed, firms

Disciplines

Business

Publication Details

Li, F., Abeysekera, I. \& Ma, S. (2014). The effect of financial status on earnings quality of Chinese-listed firms. Journal of Asia-Pacific Business, 15 (1), 4-26. 


\title{
The Effect of Financial Status on Earnings Quality of Chinese-Listed Firms
}

\author{
FENG LI, INDRA ABEYSEKERA, SHIGUANG MA* \\ University of Wollongong, Wollongong, Australia
}

\begin{abstract}
This article investigates the relation between accounting-based earnings quality attributes and the financial status of Chinese companies listed in Shanghai and Shenzhen stock exchanges from 2005 to 2007 by classifying them as either "bealthy" or "bankrupt" firms. The authors find that accruals quality, earnings predictability, and earnings smoothness are significantly different between bealthy and bankruptfirms, but not earnings persistence. Additional analysis undertaken indicates thatfirm categories (healthy, financially distressed, and bankrupt) based on financial status does not indicate distinct differences in earnings quality attributes.
\end{abstract}

KEYWORDS financial status, bealthy, bankrupt, earnings quality, China

\section{INTRODUCTION}

Due to the administrative governance approach adopted in China, regulators often rely on accounting numbers to govern the listed companies ( $\mathrm{Lu} \&$ Liu, 2007). For example, the China Securities Regulatory Commission (CSRC) requires listed firms to meet certain level of return on equity (ROE) before they can apply for a permission to issue additional shares to existing shareholders (rights issues); and the most important criterion for delisting a listed company is a reported net loss for three consecutive years (Qi, Wu, \& Wu,

\footnotetext{
* Corresponding Author: Dr. Shiguang Ma, School of Accounting and Finance, University of Wollongong, Northfields Avenue, Wollongong, New South Wales 2522, Australia. E-mail: shiguang_ma@uow.eud.au, Tel: 61242213312.
} 
2005). A peculiar feature of Chinese-listed firms is that some of them that should be declared as financially distressed and/or should be declared as bankrupt (in terms of the criteria used in developed countries) are still being listed on the stock markets in China, in contrast with those in mature stock markets in developed countries (Ronen \& Yaari, 2008).

Altman (2006) developed an emerging market score model (EMS) $\mathrm{Z}$ score to categorize firms as healthy, financially distressed, or bankrupt. The firms listed on the emerging stock markets of China can be identified under the EMS model due to the earlier noted peculiarity of the listing status of Chinese stock markets. Borrowing the EMS model Z score to categorize Chinese-listed firms into two categories, this study investi-gates the status of accounting-based earnings quality attributes between healthy and bankrupt firms as the key investigation and earnings quality attributes between healthy, financially distressed, and bankrupt firms as a supplementary investigation. Francis, LaFond, Olsson, and Schipper (2004) identified four accounting-based earnings quality attributes (accruals quality, persistence, predictability, and smoothness) and market-based earnings quality attributes (relevance, timeliness, and conservatism). This study uses accounting-based earnings attributes only as the EMS model firm classi- fication is built upon accounting data rather than market data. Although we do not rule out the notion that market-based earnings attributes can inform about the two firm categories under the EMS model, given our focus on accounting-based earnings quality, it is more appropriate to deal with market-based earnings attributes in a separate study. Our findings suggest that the bankrupt firms have the lower earnings quality measured in regards to accruals quality, earnings predictability, and earnings smoothness, but not as regards earnings persistence.

Our two motivations for this study contribute to the literature as follows. First, to the best of our knowledge, no research has been conducted to ascertain the status of the four accounting-based earnings attributes (accruals quality, earnings persistence, earnings predictability, and earnings smoothness) among the two principal firm categories (healthy and bankrupt) using the EMS Z score criterion. Second, our research article is one of the few analyses of accounting-based earnings quality attributes across the listed firms of the emerging Chinese market, based on the assumption in prior literature that desirable earnings qualities can reduce the information risk to investors in their decision making.

The next section outlines a review of relevant literature and firm classification based on financially-healthy status. Then, we explain the measures of earnings quality and develop hypotheses. After that, we design the research method, followed by the analyses on our empirical results. Finally, we conclude our research. 


\section{LITERATURE REVIEW AND FINANCIAL STATUS CLASSIFICATION}

The literature to date has characterized four earnings attributes as indicators of earnings quality: accruals quality, earnings persistence, earnings predictability, and earnings smoothness (Francis et al., 2004). Accruals quality refers to the extent to which accruals map onto the related cash flow realization, when accruals shift or adjust the recognition of cash flows over time so that the adjusted earnings becomes a better measure of firm performance (Boonlert-U-Thai, Meek, \& Nabar, 2006). Earningspersistence captures the concept of earnings sustainability; persistent earnings are viewed as desirable because they are recurring (Penman \& Zhang, 2002; Richardson, 2003). Earnings predictability refers to the ability of current earnings to predict future earnings. Earnings smoothness refers to the use of accruals to smooth earnings using management's private information to reflect earnings more accurately with cash flows from operations; low smoothness means that a firm's management has not engaged in smoothing practices (Chaney \& Lewis, 1995; Demski, 1998; Ronen \& Sadan, 1981).

The literature contains several possible earnings quality constructs. Schipper and Vincent (2003) provided three such constructs, including three derived from the time-series properties of earnings: persistence (measured as earning persistence), predictive value (measured as earnings predictability), and variability (measured as accruals quality, and earnings smoothness). Although earnings persistence and predictive value might typically go handin-hand, Schipper and Vincent noted that volatile earnings might be high quality as measured by persistence, but low quality as measured by predictive value. Francis, Olsson, and Schipper (2008) focused on how the precision of financial information in capturing one or more underlying valuation constructs affects the assessment and use of that information by investors.

The EMS model is a predictive model that combines four different financial ratios to determine the likelihood of bankruptcy among firms using a $Z$ score index (Altman, 2006). This model was first developed in the mid-1990s to provide an analytical framework for the analysis of the then-growing, but still nascent-emerging market firms issuing bonds in non-local currency (usually U.S. dollars) (Altman, 2006). In the Chinese capital market context, unusual to many other stock exchanges, some firms are in financial distress or bankrupt in terms of the criteria used in developed countries but are still being listed on the stock exchanges, flagging their near-bankruptcy or bankruptcy status to investors. Therefore, bankrupt firms have a prebankruptcy status in the Chinese stock markets. Due to the anomalous listing system in the Chinese stock exchange, we use the EMS model to split sample firm-year observations into healthy, financially distressed, and bankrupt categories using $\mathrm{Z}$ scores of firm-year observations. 
The EMS model is as follows (Altman, 2006):

$$
\mathrm{EMScore}=6.56 * \mathrm{X} 1+3.26 * \mathrm{X} 2+6.72 * \mathrm{X} 3+1.05 * \mathrm{X} 4+3.25
$$

Zones of discrimination:

$Z>5.65$ - Safe Zone (indicating healthy firms in this study)

$1.75<Z<5.65-$ Grey Zone (indicating financially distressed firms in this study)

$\mathrm{Z}<1.75-$ Bankruptcy (indicating bankrupt firms in this study).

where,

$X 1=$ working capital/total assets

$X 2=$ retained earnings $/$ total assets

$X 3=\mathrm{EBIT} /$ total assets

$X 4=$ book value of equity/total liabilities.

The constant term of 3.25 in the Model 1 is derived from the median Z score for bankrupt U.S. entities, to standardize the analysis so that a default equivalent rating is consistent with a score below 1.75 (Altman, 2006). Altman (2006) stated that the EMS model was tested on samples of manufacturers and non-manufacturers, public firms, private firms, and specific industries (e.g., retailers, telecoms, airlines, etc.), more than 20 countries including China, and its accuracy and reliability have remained high. The foundation of the EMS model is an enhancement of the $\mathrm{Z}$ score model, resulting in an EMS and its associated bond rating equivalent (BRE) (Altman, 2006). The EMS rating equivalent is then modified based on three critical factors: (1) the firm's vulnerability to currency devaluation, (2) its industry affiliation, and (3) its competitive position in the industry (Altman, 2006).

\section{MEASURES OF EARNINGS QUALITY AND RELEVANT HYPOTHESES}

The idea behind the hypotheses for this study follows from Rosner (2003). Rosner examined U.S. firms under four categories: non-stressed and nonbankrupt, stressed and non-bankrupt, non-stressed and bankrupt, and stressed and bankrupt. In that study, a given firm's stress was an ex-ante measure, and bankruptcy was an ex-post measure. The firm classification is based on the criteria developed by McKeown et al. (1991). Although their classification has a similar analogy to Altman (2006) firm classification as healthy, financially distressed, and bankrupt, their study assigns stressedbankrupt status to a firm if it exhibited any of the following symptoms: 
(1) negative working capital in the current year, (2) an earnings loss from operations in any of the three prior years to bankruptcy year, (3) an earnings loss in any of the three prior years to bankruptcy year, (4) a retained earnings deficit in any of the three prior years to bankruptcy year. According to the firm classification advanced by McKeown et al., a firm later going into (ex-post) bankruptcy but not showing any of the four symptoms prior to bankruptcy was identified as non-stressed and bankrupt, and a firm later avoiding bankruptcy but showing any of the four symptoms was identified as stressed and non_bankrupt. Rosner (2003) examined income-increasing earnings manipulation of these four firm categories using various proxies: receivables and inventory overstatement; payables and accrual expenses understatement; net working capital/current accruals overstatement; property, plant and equipment overstatement; and poor cash flow indicators. Rosner found that firms that appear (ex-ante) non-stressed and (ex-post) bankrupt hid their financial stress through earnings manipulation, resembling Securities Exchange Commission-sanctioned fraud firms.

Although this study examines earnings quality attributes rather than earnings manipulation as Rosner (2003) did, she demonstrated that firm behavior can be studied under broad firm classifications. A firm classification, specifically ex-ante non-stressed and ex-post bankrupt are likely to hide their earnings quality through earnings manipulation. Using Rosner as a learning platform, we classify firms into broad spectra, but we posit that the firm classification put forward by McKeown et al. (1991) is inappropriate to Chinese listed firms, because Chinese stock exchanges allow firms that are technically bankrupt by Western norms to continue their listing status, making them ex-ante bankrupt firms. We instead use Altman's (2006) firm classification that uses financial status as the construct as McKeown et al.'s study did to identify firms as healthy, financially distressed, and bankrupt. Financially distressed firms under Altman are similar to McKeown et al.'s classification: non-stressed and bankrupt, and stressed and non-bankrupt firms, and in this study we disregarded financially disTressed firms for the main empirical model, because as found by Rosner it is likely that they manipulate earnings, and their earnings quality is driven by earnings manipulation.

In relation to Altman's (2006) Z score that is founded on the strength of firms' balance sheets, it is likely that healthy firms have higher earnings quality than bankrupt firms, and therefore these firms' categories are significantly different, because strength of accounting-based information is more important in determining earnings quality attributes (Barker \& Imam, 2008). The choice of the four accounting-based earnings attributes are chosen because each attribute informs a different dimension of earnings quality. The accruals quality is a measure that informs about the cost of funds (debt and equity); earnings persistence informs about earnings recurrence or sustenance of earnings from one reporting period to another; earnings 
predictability informs about earnings forecast accuracy, an aspect desirable to standard setters, analysts, and firm valuations (e.g. for mergers, and acquisitions); and earnings smoothness informs regarding the extent to which 190 managers have contributed their privately-held information about the firm to report a more useful earnings number (Francis et al., 2004). Each earnings attribute is outlined next.

\section{Accruals Quality}

Accruals quality as a measure of earnings quality is based on the view that earnings can be matched more closely into cash flow from operations. Dechow and Dichev (2002) measured earnings quality as capturing the mapping of working capital accruals onto last-period, current-period, and next-period cash-flow from operations. A typical Dechow-Dichev accruals quality measure begins with a model that relates total current accruals to lagged, current, and future cash flow from operations (Francis et al., 2008). The measure of accruals quality in this study is based on Dechow and Dichev's model as follows:

$$
\begin{aligned}
\frac{\text { TCA }_{j, t}}{\text { TotalAsset }_{j, t-1}}= & b_{0}+b_{1} * \frac{C F O_{j, t-1}}{\text { TotalAsset }_{j, t-1}}+b_{2} * \frac{C F O_{j, t}}{\text { TotalAsset }_{j, t-1}} \\
& +b_{3} * \frac{C F O_{j, t+1}}{\text { TotalAsset }_{j, t-1}}+\varepsilon_{j, t}
\end{aligned}
$$

where,

$T C A_{j, t}=$ Firm $j$ 's total current accruals in $t\left(\Delta \mathrm{CA}_{\mathrm{j}, \mathrm{t}}-\Delta \mathrm{CL}_{\mathrm{j}, \mathrm{t}}-\Delta\right.$ Cash $_{\mathrm{j}, \mathrm{t}}$ $\left.+\Delta \mathrm{STDEBT}_{\mathrm{j} . \mathrm{t}}+\Delta \mathrm{TP}_{\mathrm{j}, \mathrm{t}}\right)$

Total Asset $j_{j, 1}=$ Firm $j$ 's total assets in year $t-1$

$C F O_{j, t}=$ Firm $j$ 's cash flow from operations in year $t$

$C A_{j, t}=$ Firm $j$ 's current assets in year $t$

$C L_{j, t}=$ Firm $j$ 's current liabilities in year $t$

Cash $_{j, t}=$ Firm $j$ 's cash in year $t$

$S \operatorname{SDEBT}_{j, t}=$ Firm $j$ 's debt in current liabilities in year $t$ $T P_{j, t}=$ Firm $j$ 's taxes payable in year $t$.

The measure of accruals quality is based on the standard deviation of estimated residual $\sigma\left(\hat{\varepsilon}_{j, t}\right)$, which refers to the extent to which current accruals map onto operating cash-flow realizations. Large (small) values of estimated residual correspond to lower (higher) accruals quality and lower (higher) earnings quality.

Accruals quality measures the precision with which accruals predict future cash flows (Dechow \& Dichev, 2002; Francis, LaFond, Olsson, \& 
Schipper, 2005; McNichols, 2002). Prior evidence that firms with higher accruals quality have lower cost of capital suggests that high-quality accruals improve firms' earnings-based valuation (Aboody, Mary, \& Ron, 2004; Francis et al., 2004). We expect that healthy firms have a cash-flow position in the past, present, and future and that are most likely to mirror their accruals, thereby informing higher accruals quality. The bankrupt firms, on the other hand, are likely to have a poor cash flow position in the past, present, and future and are less likely to match their accruals with cash-flow position, thereby informing lower accruals quality. Based on our expectations, we state the hypothesis of accruals quality as follows:

Hypothesis 1: Accruals quality in healthy firms is significantly higher than that of bankrupt firms.

\section{Earnings Persistence}

To measure persistence, researchers generally estimate a regression of the future value of the variable on its current value (Dechow \& Schrand, 2004). Sloan (1996) evaluated whether cash flow from operations and accruals have different implications for the persistence of future earnings and tested the ability of earnings to forecast future earnings, concluding that those earnings that can accurately forecast future earnings are more persistent.

Kormendi and Lipe (1987) used firm-level regressions of current earnings on previous year's earnings to estimate the slope-coefficient estimates of earnings persistence. This study employs the measure in Kormendi and Lipe to test earnings persistence using the following equation:

$$
\frac{\text { Earn }_{j, t}}{\text { TotalAssets }_{j, t-1}}=\alpha+\delta_{1} * \frac{\text { Earn }_{j, t-1}}{\text { TotalAsset }_{j, t-1}}+V_{j, t}
$$

where,

Earn $_{j, t}=$ Firm's $j$ net income before extraordinary items in year $t$ Earn $_{j, t 1}=$ Firm's $j$ net income before extraordinary items in year $\leftarrow 1$.

The measure capturing earnings persistence is based on the slopecoefficient estimate $\left(\delta_{1}\right)$. Values of $\delta_{1}$ close to one (or greater than one) indicate highly persistent earnings whereas values close to zero imply highly transitory earnings. Persistent earnings are viewed as higher quality, whereas transitory earnings are viewed as lower quality.

Earnings persistence refers to the likelihood a firm's earnings levels will recur in future periods (Nichols \& Wahlen, 2004). However, when firms report earning losses, it can be that those firms recognize expected loss transactions as incurred in that reporting period (Basu, 1997). By including 
these expected but unrealized losses in a current reporting period, the firm converts a series of future loss transactions into a single transitory loss as reported in the current period. Secondly, losses can also indicate that the firm is likely to liquidate the assets generating the loss (Hayn, 1995). Third, a realized loss could result from a negative shock accompanied by liquidation of assets or cash expenditures. The negative shocks are likely to be immediately realized, whereas positive shocks are realized gradually over time. These factors make earning losses less persistent than earning gains (Hayn, 1995). Because bankrupt firms have poor balance sheets partly because of more earning losses made over the reporting periods, we expect bankrupt firms to demonstrate less persistent earnings than healthy firms. We state the hypothesis of earnings persistence as follows:

Hypothesis 2: Earnings persistence of healthy firms is significantly higher than that of bankrupt firms.

\section{Earnings Predictability}

Dichev and Tang (2009) investigated the relation between earnings volatility and earnings predictability and found a negative relationship between earnings volatility and earnings predictability. They also concluded that earnings volatility has substantial predictive power spanning up to 5 years into the future.

Lipe (1990) provided a measure of earnings predictability as it reflects the variance of earnings shocks: with the increase in variance, the predictability decreases. Francis et al. (2004) measured earnings predictability using the square root of the estimated error-variance from the earnings-persistence equation. In this study, earnings predictability is calculated using the square root of the error variance from equation of earnings persistence:

$$
\text { Pred }_{j, t}=\sqrt{\sigma^{2}\left(\hat{v}_{j, t}\right)}
$$

where,

$\sigma^{2}\left(\hat{v}_{j, t}\right)=$ Estimated-error variance of firm $j$ in year $t$, calculated from Equation 3.

Our measure of earnings predictability is the standard deviation of the residuals $\left(\hat{v}_{j, t}\right)$ from Equation 3. Large values of Pred ${ }_{j, t}$ imply less predictable earnings and lower earnings quality.

A number of important applications of accounting data require the prediction of earnings. For example, valuation research and practice typically use projections of earnings to derive estimates of firms' equity value. 
A related application is the use of accounting data to derive, and possibly improve on, analysts' earnings forecasts. Dichev and Tang (2009) found that the consideration of earnings predictability brings substantial improvements in the prediction of short- and long-term earnings, reducing errors in predictability. We expect healthy firms to have more predictable earnings than bankrupt firms, which are likely to have more earning losses, and are likely to engage in pernicious earnings management. We state the hypothesis of earnings predictability as follows:

Hypothesis 3: Earnings predictability in healthy firms is significantly higher than that of bankrupt firms.

\section{Earnings Smoothness}

Discussions of the benefits of smooth earnings include Demski (1998), Wysocki (2004), and Francis et al. (2004). Arguments that smoothness is a desirable earnings attribute derive from the view that managers use their private information about future earnings to smooth out transitory fluctuations and thereby achieve a more representative, hence more useful, reported earnings number.

In measuring smoothness, Leuz, Nanda, and Wysocki (2003) used cash flow from operations as a reference construct for unsmoothed earnings and measure smoothness as the ratio of earnings variability (i.e., smoothed) to 310 cash flow from operations variability (i.e., unsmoothed). Bowen, Rajgopal, and Venkatachalam (2003) measured earnings smoothness as the standard deviation of cash flow from operations divided by the standard deviation of earnings. Francis et al. (2004) measured earnings smoothness as the ratio of standard deviation of net income before extraordinary items as proposed by Bowen et al. but standardized them by lagged total assets, and this study employs the following equation:

$$
\text { Smooth }_{j, t}=\frac{\sigma\left(\mathrm{CFO}_{j, t} / \text { TotalAssets }_{j, t-1}\right)}{\sigma\left(\text { Earn }_{j, t} / \text { TotalAsset }_{j, t-1}\right)}
$$

where,

$\sigma=$ Firm $j$ 's standard deviation

$C F O_{j, t}=$ Firm $j$ 's operating cash flows in year $t$

$\sum\left(\right.$ Earn $\left._{j, t}\right)=$ Firm $j$ 's net income before extraordinary items in year $t$.

Ratios in excess of one indicate more variability in operating cash flows relative to the variability of earnings, indicating a wider disparity between unsmoothed earnings and smoothed earnings. The disparity is considered to 
be due to the practice of using accruals inappropriately. Thus, large (small) values of smooth indicate more (less) earnings smoothness and low (high) earnings quality. As noted earlier, the financial statements of near-bankrupt firms are more likely to reflect evidence of material overstatements, presumably motivated by a desire to conceal signs of distress, than those of non-bankrupt firms (Rosner, 2003).

An earnings management strategy that has survived the test of time is smoothing. Smoothing can be the outcome in some circumstances, for instance, due to the dampening of fluctuations in the series of reported earnings (Buckmaster, 2001). Due to the administrative governance approach adopted in China, the regulators often rely on accounting numbers to govern the listed companies, and the CSRC requires listed firms to meet certain benchmarks on ROE before they can apply for permission to issue additional shares to existing shareholders (rights issues). The most important criterion for delisting a listed company is reported net loss for three consecutive years. Poor-performing firms, such as those that are bankrupt, are likely to use private perniciously managed earnings through inappropriate use of accruals are less representative of firms' cash flows from operations. We believe that bankrupt firms are more likely to manipulate their earnings to avoid delisting and have strong incentives to manage earnings to meet necessary thresholds, and that healthy firms are less likely to do so. We state the hypothesis of earnings smoothness as follows:

Hypothesis 4: Earnings smoothness in healthy firms is significantly higher than that of bankrupt firms.

\section{METHOD}

\section{Sample}

The sample comprises firms that issued A-shares and were listed on the Shanghai and Shenzhen stock exchanges for the fiscal years 2005 to 2007. This study measures the four accounting-based earnings attributes on a firmand year-specific basis, using the relevant accounting information for rolling 5 -year windows, t-4, . . t. For example, the firm-years 2001 to 2005 are used to calculate the earnings attributes for the year 2005, the firm-years 2002 to 2006 for the year 2006, and the firm-years 2003 to 2007 for the year 2007. Because the computation of accruals quality requires past and future one firm-year's observation data, so we cover the data period from 2000 to 2008.

To mitigate concern that missing information in firm-year observations might reduce validity, we ensure that data on all variables are available for 
each firm-year observation for the sample period. The data are collected from the China Stock Market and Accounting Research (CSMAR) Financial Databases developed by the Shenzhen GTA Information Technology Co. After eliminating firms in banks and financial institutions, the final sample has a total of 2,961 firm-year observations for the period 2005 to 2007, which consisting of 1,046 healthy, 1,669 financially distressed and 246 bankrupt firm-year observations respectively.

\section{The Model and Variables}

The study includes accrual quality of earnings (AQ), persistence of earnings (PERS), predictability of earnings (PRED), and smoothness of earnings (SMOOTH) as dependent variables in four separate econometric models to examine the relationship between earnings quality attributes, and healthy versus bankrupt firms. Table 1 summarizes the operational dependent and independent variables, and their measurement attributes. The following regression equation tests data by pooling firms across 3 years. We use random-effect estimation in the panel data set, as variations among firms are of interest in this study, and helps in generalizing findings to Chinese-listed firms.

$$
\begin{aligned}
\text { Dependent Variable }_{\mathrm{it}}= & \mathrm{b}_{0}+\mathrm{b}_{1} \mathrm{HVSB}_{\mathrm{it}}+\mathrm{b}_{2} \mathrm{CFO}_{\mathrm{it}}+\mathrm{b}_{3} \text { SALES }_{\mathrm{it}}+\mathrm{b}_{4} \mathrm{SIZE}_{\mathrm{it}} \\
& +\mathrm{b}_{5} \mathrm{OPCYCL}_{\mathrm{it}}+\mathrm{b}_{6} \mathrm{NEGEARN}_{\mathrm{it}}+\mathrm{z}
\end{aligned}
$$

$t=2005,2006$, and 2007 years, and $i$ is firm-year observation.

In this econometric model, higher $\mathrm{AQ}$ value means lower earnings quality. Higher PERS value means higher earnings quality. Higher PRED value means lower earnings quality. Higher SMOOTH value means lower earnings quality. We identify healthy firms as those with an EMS Z score greater than 5.65, financially distressed as those with an EMS Z score between 5.65 and 1.75 , and bankrupt firms as those with an EMS Z score less than 1.75. We control for cash flow variability (CFO), sales variability (SALES), firm size (SIZE), operating cycle length (OPCYCL), and negative earnings (NEGEARN) in the past 5 years. The cash-flow volatility and sales volatility indicate uncertainty of earnings and lower earning quality. Larger firms are likely to maintain higher earnings quality than smaller firms. The longer operating cycles indicate greater uncertainty of earnings, and lower earnings quality. The negative earnings are past earnings losses; any estimations made about earnings during the loss period can indicate substantial estimation errors, and indicates lower earnings quality (Dechow \& Dichev, 2002). 
TABLE 1 Variable Definitions and Measurement

\begin{tabular}{|c|c|c|c|}
\hline Variable & Proxy & Measurement & Expected Values \\
\hline \multicolumn{4}{|l|}{ Dependent } \\
\hline $\mathrm{AQ}$ & Accrual quality & $\begin{array}{l}\text { Standard deviation of the estimated residual using } \\
\text { Dechow and Dechev (2002) regression model where } \\
\text { total current accruals are related to previous, current, } \\
\text { and future period cash flows, using five-year rolling } \\
\text { window }\end{array}$ & - ve to $\infty$ \\
\hline PERS & Earnings persistence & $\begin{array}{l}\text { Slope coefficient between current period earnings } \\
\text { regressed over previous period earnings using } \\
\text { Kormendi and Lipe (1987) regression model, using a } \\
\text { five-year rolling window }\end{array}$ & -ve to $\infty$ \\
\hline PRED & Earnings predictability & $\begin{array}{l}\text { Standard deviation of the estimated residual using } \\
\text { Kormendi and Lipe (1987) regression model that } \\
\text { estimate earnings persistence, using a five-year } \\
\text { rolling window }\end{array}$ & 0 to $\infty$ \\
\hline SMOOTH & Earnings smoothness & $\begin{array}{l}\text { Ratio for standard deviation of the cash flows from } \\
\text { operation over standard deviation of earnings in } \\
\text { current periods, using Bowen et al. (2003) no } \\
\text { constant regression model, using a five-year rolling } \\
\text { window }\end{array}$ & 0 to $\infty$ \\
\hline $\begin{array}{l}\text { Predictor } \\
\text { H versus B } \\
\text { (HVSB) }\end{array}$ & Healthy versus bankrupt firms & $\begin{array}{l}\text { Firms evaluated for financial health using Emerging } \\
\text { Market Score ( } Z \text { ) of Altman (2006) for each firm year } \\
\text { Healthy firm codes } 1 \text { and bankrupt firm codes } 0 \text {. }\end{array}$ & 0 or 1 \\
\hline Control & & & 0 to $\infty$ \\
\hline $\mathrm{CFO}$ & Cash flows & $\begin{array}{l}\text { Standard deviation of firm's cash flows from } \\
\text { operations, calculated over 5-year rolling window for } \\
\text { each firm year (Francis et al., 2004) }\end{array}$ & 0 to $\infty$ \\
\hline SALES & Sales revenue & $\begin{array}{l}\text { Standard deviation of firm's sales, calculated over } \\
\text { 5-year rolling window for each firm year (Francis } \\
\text { et al., 2004) }\end{array}$ & \\
\hline SIZE & Firm size & Log of firm's total assets for each firm year & 0 to $\infty$ \\
\hline OPCYCL & Operating cycle length & Log of firm's operating cycle for each firm year & $-_{\mathrm{ve}}$ to $+_{\mathrm{ve}}$ \\
\hline NEGEARN & Negative earnings & $\begin{array}{l}\text { Firm reporting negative earnings in any of the past } \\
5 \text { years for each firm year, which codes } 1 \text {, }\end{array}$ & 0 or 1 \\
\hline
\end{tabular}




\section{RESULTS AND ANALYSES}

\section{Descriptive Statistics}

Table 2 presents descriptive statistics. Earnings quality attributes are positively skewed, and with a wide variation among firms. However, we inspect the stem and leaf plot and find no outliers which significantly influence findings. The most firms' AQ is around 0.04, PERS is around 0.10, PRED is around 0.03 , and SMOOTH is around 0.06 . The variables controlled for earnings quality attributes show that the most likely values are similar to mean values of firm-year observations, and this could be because the values were either standardized by $\log$ value (SIZE, and OPCYCL), or statistical value (CFO, SALES). As evident from minimum values, some AQ and PERS values because of firm-year observations report negative earnings, with the most likely scenario of these firms being that the operating cash flows are less volatile than earnings. All firms have made earnings losses during any of the past five years prior to their firm-year observations.

Table 3 provides a correlation matrix for variables. AQ, PRED, and SMOOTH have same signs, and PERS has opposite sign, confirming that the lower values of the former three indicate higher earnings quality, and the lower value of PERS indicates lower earnings quality. Cash flows from operations variability significantly and positively associate AQ, PRED, and SMOOTHN. Firm-size significantly and negatively associates with all attributes of earnings quality. The behaviou of firm size with earnings quality attributes and sales volatility with earnings quality attributes (AQ, PERS, and PRED) are contrary to our expectations from previous studies. These unexpected findings are due to firms in the study widely differing in cash flow volatility and sales volatility as evident from their standard deviations being much larger than mean values. Smaller firms are likely to associate with higher earnings quality, which is contrary to findings from firms located

TABLE 2 Descriptive Statistics

\begin{tabular}{lcccrrr}
\hline & Observation & Mean & $S D$ & Minimum & Maximum & Median \\
\hline AQ & 2961 & 0.13 & 0.47 & -2.23 & 12.82 & 0.04 \\
PERS & 2961 & 0.34 & 1.09 & -17.13 & 14.97 & 0.10 \\
PRED & 2961 & 0.15 & 0.48 & 0.00 & 8.95 & 0.03 \\
SMOOTH & 2961 & 0.37 & 0.77 & 0.00 & 8.99 & 0.06 \\
CFO & 2961 & 0.08 & 0.20 & 0.00 & 4.47 & 0.05 \\
SALES & 2961 & 0.20 & 0.31 & 0.00 & 7.80 & 0.13 \\
SIZE & 2961 & 9.27 & 0.50 & 6.15 & 11.27 & 9.27 \\
OPCYCL & 2961 & 1.54 & 0.54 & -3.74 & 4.32 & 1.49 \\
NEGEARN & 2961 & 1.00 & 0.02 & 0.00 & 1.00 & 1.00 \\
\hline
\end{tabular}

Total 2,961 firm-year observations for the period 2005 to 2007; AQ $=$ Accrual quality; PERS $=$ Earnings persistence; $\mathrm{PRED}=$ Earnings predictability; SMOOTH $=$ Earnings smoothness; $\mathrm{CFO}=$ Standard deviation of cash flows scaled by assets; SALES $=$ Standard deviation of sales revenue scaled by assets; SIZE $=$ Log of total assets; OPCYCL $=$ Log of operating cycle length; NEGEARN = Negative earnings dummy. 
TABLE 3 Correlation Matrixes

\begin{tabular}{|c|c|c|c|c|c|c|c|c|c|}
\hline & AQ & PERS & PRED & SMOOTH & $\mathrm{CFO}$ & SALES & SIZE & OPCYCL & NEGEARN \\
\hline AQ & 1 & & & & & & & & \\
\hline PERS & $-0.034^{*}$ & 1 & & & & & & & \\
\hline Probability & 0.063 & & & & & & & & \\
\hline PRED & $0.032^{*}$ & $-0.038^{* *}$ & 1 & & & & & & \\
\hline Probability & 0.078 & 0.039 & & & & & & & \\
\hline SMOOTH & $0.271^{* * *}$ & $-0.099^{* * *}$ & 0.007 & 1 & & & & & \\
\hline Probability & 0.000 & 0.000 & 0.715 & & & & & & \\
\hline $\mathrm{CFO}$ & $0.069^{* * *}$ & -0.014 & $0.136^{* * *}$ & $0.145^{* * *}$ & 1 & & & & \\
\hline Probability & 0.000 & 0.434 & 0.000 & 0.000 & & & & & \\
\hline SALES & 0.006 & -0.009 & $0.037^{* *}$ & -0.003 & $0.089^{* * *}$ & 1 & & & \\
\hline Probability & 0.732 & 0.633 & 0.044 & 0.889 & 0.000 & & & & \\
\hline SIZE & $-0.072^{* * *}$ & $0.090^{* * *}$ & $-0.209^{* * *}$ & $-0.125^{* * *}$ & $-0.081^{* * *}$ & 0.005 & 1 & & \\
\hline Probability & 0.000 & 0.000 & 0.000 & 0.000 & 0.000 & 0.769 & & & \\
\hline OPCYCL - & $-0.064^{* * *}$ & 0.013 & $-0.031^{*}$ & $-0.071^{* * *}$ & $0.033^{*}$ & $0.226^{* * *}$ & $0.326^{* * *}$ & 1 & \\
\hline Probability & 0.001 & 0.468 & 0.087 & 0.000 & 0.076 & 0.000 & 0.000 & & \\
\hline NEGEARN & 0.004 & -0.004 & 0.005 & 0.007 & 0.003 & 0.006 & -0.029 & -0.005 & 1 \\
\hline Probability & 0.816 & 0.819 & 0.786 & 0.699 & 0.880 & 0.733 & 0.118 & 0.777 & \\
\hline
\end{tabular}

Total 2,961 firm-year observations for the period 2005 to 2007; AQ $=$ Accrual quality; PERS $=$ Earnings persistence; PRED $=$ Earnings predictability; SMOOTH $=$ Earnings smoothness; $\mathrm{CFO}=$ Standard deviation of cash flows scaled by assets $;$ SALES $=$ Standard deviation of sales revenue scaled by assets; SIZE $=\log$ of total assets; OPCYCL $=$ Log of operating cycle length; NEGEARN $=$ Negative earnings dummy.

*Significant at better than the $10 \%$ level, ${ }^{* *}$ Significant at better than the $5 \%$ level, ${ }^{* * *}$ Significant at better than the $1 \%$ level. 
in developed country stock markets. Firms with longer operating cycles are large firms and firms with more sales volatility. Longer operating cycle associates with lower earnings quality, and negative earnings associate with lower earnings quality.

\section{Regression Results}

As reported in Table 4, each earnings quality attribute is compared between healthy firms and bankrupt firms, and the finding that each earnings quality attribute is significantly different is demonstrated.

Results for Accruals Quality (Hypothesis 1). As shown in Table 5, healthy firms are significantly higher than bankrupt firms in AQ of earnings $\left(b_{1}=-0.134\right.$, probability $\left.=.033\right)$, and conform to Hypothesis 1 , with healthy

firms reporting higher accruals quality. Firms with shorter operating cycles reported higher AQ than those having longer operating cycles. The other established variables in the literature had no significant influence on accruals quality.

TABLE 4 Results of Mean Test and $t$ Test for Accounting-based Four Earnings-Attributes Quality between healthy firms and bankrupt firms

\begin{tabular}{lccrc}
\hline & Mean Health firm & Mean Bankrupt firm & Difference & $t$ Statistic \\
\hline Firm Number & 1,046 & 246 & & \\
AQ & 0.062 & 0.132 & -0.070 & $-3.95^{* * *}$ \\
PERS & 0.671 & 0.438 & 0.233 & $1.67^{*}$ \\
PRED & 0.035 & 0.240 & -0.205 & $-11.22^{* * *}$ \\
SMOOTH & 0.076 & 0.302 & -0.226 & $-7.54^{* * *}$ \\
\hline
\end{tabular}

Sample of 1,292 firm-year observations consists of 1,046 healthy firm-years and 246 bankrupt firm-years; $A Q=$ Accrual quality; PERS $=$ Earnings persistence; PRED $=$ Earnings predictability; SMOOTH $=$ Earnings smoothness.

*Significant at better than the $10 \%$ level, ${ }^{* * *}$ Significant at better than the $1 \%$ level.

TABLE 5 Panel Data Regression Results for Accruals Quality

\begin{tabular}{lccrccc}
\hline & Coefficient & $\begin{array}{c}\text { Standard } \\
\text { Error (robust) }\end{array}$ & Z score & Probability & $\begin{array}{c}\text { Confidence } \\
\text { Interval (low) }\end{array}$ & $\begin{array}{c}\text { Confidence } \\
\text { Interval (high) }\end{array}$ \\
\hline H versus B & $-0.134^{* *}$ & 0.060 & -2.24 & 0.025 & -0.252 & -0.017 \\
OPCYCL & $-0.074^{* *}$ & 0.035 & -2.14 & 0.033 & -0.142 & -0.006 \\
NEGEARN & $0.047^{* * *}$ & 0.014 & 3.46 & 0.001 & 0.021 & 0.074 \\
CFO & $0.194^{*}$ & 0.180 & 1.08 & 0.279 & -0.158 & 0.546 \\
SALES & -0.003 & 0.035 & -0.09 & 0.931 & -0.071 & 0.065 \\
SIZE & -0.008 & 0.041 & -0.20 & 0.844 & -0.087 & 0.072 \\
Constant & 0.389 & 0.382 & 1.02 & 0.308 & -0.359 & 1.137 \\
Adjusted R $R^{2}$ & 0.125 & & & & & \\
Observation & 1,292 & & & & & \\
\hline
\end{tabular}

Sample of 1,292 firm-year observations consists of 1,046 healthy firm-years and 246 bankrupt firm-years; $H$ versus $\mathrm{B}=$ Healthy versus bankrupt firm dummy; OPCYCL = Log of operating cycle length; NEGEARN = Negative earnings dummy; $\mathrm{CFO}=$ Standard deviation of cash flows scaled by assets flows scaled by assets; SALES $=$ Standard deviation of sales revenue scaled by assets; SIZE $=$ Log of total assets.

*Significant at better than the $10 \%$ level, ${ }^{* *}$ Significant at better than the $5 \%$ level, ${ }^{* * *}$ Significant at better than the $1 \%$ level. 
TABLE 6 Panel Data Regression Results for Persistence

\begin{tabular}{|c|c|c|c|c|c|c|}
\hline & Coefficient & $\begin{array}{c}\text { Standard } \\
\text { Error (robust) }\end{array}$ & Z score & Probability & $\begin{array}{c}\text { Confidence } \\
\text { Interval (low) }\end{array}$ & $\begin{array}{l}\text { Confidence } \\
\text { Interval (high) }\end{array}$ \\
\hline$H$ versus $B$ & -0.153 & 0.272 & -0.56 & 0.573 & -0.687 & 0.380 \\
\hline OPCYCL & $-0.132^{* *}$ & 0.066 & -1.99 & 0.046 & -0.262 & -0.002 \\
\hline NEGEARN & $-0.347^{* * *}$ & 0.025 & -13.93 & 0.000 & -0.396 & -0.298 \\
\hline $\mathrm{CFO}$ & 0.096 & 0.160 & 0.60 & 0.549 & -0.218 & 0.410 \\
\hline SALES & 0.166 & 0.144 & 1.16 & 0.248 & -0.115 & 0.447 \\
\hline SIZE & $0.436^{* *}$ & 0.172 & 2.54 & 0.011 & 0.099 & 0.772 \\
\hline Constant & $-2.954^{* *}$ & 1.464 & -2.02 & 0.044 & -5.824 & -0.084 \\
\hline Adjusted $R^{2}$ & 0.100 & & & & & \\
\hline Observation & 1,292 & & & & & \\
\hline
\end{tabular}

Sample of 1,292 firm-year observations consists of 1,046 healthy firm-years and 246 bankrupt firm-years; $H$ versus $\mathrm{B}=$ Healthy versus bankrupt firm dummy; OPCYCL $=$ Log of operating cycle length; NEGEARN = Negative earnings dummy; CFO = Standard deviation of cash flows scaled by assets; SALES = Standard deviation of sales revenue scaled by assets; SIZE $=$ Log of total assets.

*Significant at better than the $10 \%$ level, ${ }^{* *}$ Significant at better than the $5 \%$ level, ${ }^{* * *}$ Significant at better than the $1 \%$ level.

Results for Earnings Persistence (Hypothesis 2). Table 6 reports results for persistence earnings quality. There is no significant difference between healthy and bankrupt firms in earnings persistence quality and is not consistent with Hypothesis $2\left(\mathrm{~b}_{1}=-0.153\right.$, probability $\left.=.573\right)$. There is less likelihood that firms that produce earnings gain would maintain their status quo, or the firms that report earnings losses maintain their status quo over the reporting periods. However, firms with shorter operating cycles positively and significantly influence earnings persistence, as a shorter operating cycle can reduce earnings uncertainty and allow firms to maintain their earnings position with greater accuracy. Firms that report negative earnings significantly associate with lower earnings persistence, suggesting greater uncertainty of maintaining consistent earnings over reporting periods.

Results for Earnings Predictability (Hypothesis 3). As reported in Table 7, healthy firms are significantly higher than bankrupt firms in earnings predictability $\left(\mathrm{b}_{1}=-0.292\right.$, probability $\left.=.000\right)$. This is consistent with Hypothesis 3, with healthy firms reporting higher earnings predictability. Although earnings losses are likely to behave in a more variable fashion than earnings gains, because healthy and bankrupt firms have made earnings losses in any of the past 5 years prior to their firm-year observations, the impact of earnings losses on earnings predictability is, therefore, not a distinct feature for Chinese-listed bankrupt firms. Contrary to prior studies, firms in this study with more volatile cash flows from operations report more predictable earnings, and firms with longer operating cycles report higher earnings pre- dictability. The other established variables in the literature have no significant influence on earnings predictability.

Results for Earnings Smoothness (Hypothesis 4). As shown in Table 8, healthy firms are significantly higher than bankrupt firms in earnings smoothness ( $b_{1}=-0.300$, probability $\left.=.002\right)$, and conform to Hypothesis 4 , with healthy 
TABLE 7 Panel Data Regression Results for Predictability

\begin{tabular}{lcccccc}
\hline & \multicolumn{3}{c}{$\begin{array}{c}\text { Standard } \\
\text { Coefficient }\end{array}$} & $\begin{array}{c}\text { Error (robust) } \\
\text { Z score }\end{array}$ & $\begin{array}{c}\text { Probability } \\
\text { Interval (low) }\end{array}$ & $\begin{array}{c}\text { Confidence } \\
\text { Interval (high) }\end{array}$ \\
\hline H versus B & $-0.292^{* * *}$ & 0.066 & -4.43 & 0.00 & -0.421 & -0.163 \\
OPCYCL & $0.063^{* *}$ & 0.030 & 2.09 & 0.04 & 0.004 & 0.121 \\
NEGEARN & -0.016 & 0.024 & -0.65 & 0.52 & -0.063 & 0.032 \\
CFO & $0.420^{\text {*** }}$ & 0.084 & 4.97 & 0.00 & 0.254 & 0.585 \\
SALES & 0.000 & 0.040 & 0.00 & 1.00 & -0.078 & 0.078 \\
SIZE & $-0.123^{* * *}$ & 0.034 & -3.62 & 0.00 & -0.190 & -0.056 \\
Constant & $1.423^{* * *}$ & 0.313 & 4.55 & 0.00 & 0.810 & 2.037 \\
Adjusted R $R^{2}$ & 0.116 & & & & & \\
Observation & 1,292 & & & & & \\
\hline
\end{tabular}

Sample of 1,292 firm-year observations consists of 1,046 healthy firm-years and 246 bankrupt firm-years; $H$ versus $\mathrm{B}=$ Healthy versus bankrupt firm dummy; OPCYCL = Log of operating cycle length; NEGEARN = Negative earnings dummy; CFO = Standard deviation of cash flows scaled by assets; SALES = Standard deviation of sales revenue scaled by assets; SIZE $=$ Log of total assets.

*Significant at better than the $10 \%$ level, ${ }^{* *}$ Significant at better than the $5 \%$ level, ${ }^{* * *}$ Significant at better than the $1 \%$ level.

TABLE 8 Panel Data Regression Results for Smoothness

\begin{tabular}{|c|c|c|c|c|c|c|}
\hline & Coefficient & $\begin{array}{c}\text { Standard } \\
\text { Error (robust) }\end{array}$ & Z score & Probability & $\begin{array}{c}\text { Confidence } \\
\text { Interval (low) }\end{array}$ & $\begin{array}{l}\text { Confidence } \\
\text { Interval (high) }\end{array}$ \\
\hline$H$ versus $B$ & $-0.300^{* * *}$ & 0.095 & -3.16 & 0.002 & -0.486 & -0.114 \\
\hline OPCYCL & -0.184 & 0.167 & -1.10 & 0.270 & -0.510 & 0.143 \\
\hline NEGEARN & $0.095^{* * *}$ & 0.019 & 4.91 & 0.000 & 0.057 & 0.132 \\
\hline $\mathrm{CFO}$ & $0.318^{* * *}$ & 0.112 & 2.84 & 0.005 & 0.098 & 0.537 \\
\hline SALES & -0.011 & 0.068 & -0.16 & 0.870 & -0.145 & 0.123 \\
\hline SIZE & 0.017 & 0.090 & 0.19 & 0.849 & -0.159 & 0.193 \\
\hline Constant & 0.603 & 0.739 & 0.82 & 0.415 & -0.846 & 2.052 \\
\hline Adjusted $\mathrm{R}^{2}$ & 0.04 & & & & & \\
\hline Observation & 1,292 & & & & & \\
\hline
\end{tabular}

Sample of 1,292 firm-year observations consists of 1,046 healthy firm-years and 246 bankrupt firm-years; $H$ versus $\mathrm{B}=$ Healthy versus bankrupt firm dummy; OPCYCL $=$ Log of operating cycle length; NEGEARN = Negative earnings dummy; $\mathrm{CFO}=$ Standard deviation of cash flows scaled by assets ; SALES = Standard deviation of sales revenue scaled by assets; SIZE $=$ Log of total assets.

*Significant at better than the $10 \%$ level, ${ }^{* *}$ Significant at better than the $5 \%$ level, ${ }^{* * *}$ Significant at better than the $1 \%$ level.

firms reporting higher accruals quality. Firms that report more volatile cash flows from operations, smaller firms, and firms with shorter operating cycles positively influence higher quality of earnings smoothness. In such instances, it is likely that the private information which managers include to adjust earnings through accruals contribute to accurate matching of cash flows from operations volatility with earnings volatility.

\section{Additional Analysis}

As reported in Appendix A, we identify financially distressed (FD) firms (1,669 firm-year observations) as an additional firm category $(\mathrm{FD}=0)$ and regress pooled data with healthy firms $(\mathrm{H}=1)$, excluding bankrupt firms. Accruals quality and earnings persistence are not significantly different 
between the two firm categories, but earnings predictability and earnings smoothness are significantly different. We conduct an analysis that compares financially-distressed firms $(F D=1)$ and bankrupt firms $(B=0)$, excluding healthy firms. The negative earnings have high correlation with each earnings attribute in the empirical model, and therefore are dropped from the panel data regression. As reported in Appendix B, accruals quality, and earnings predictability are significantly different between financially distressed and bankrupt firms, but not earnings persistence and earnings smoothness. Findings therefore suggest that financially distressed firms are similar to healthy firms in relation to accruals quality, and similar to bankrupt firms in relation to earnings smoothness. Financially distressed firms are significantly different from healthy and bankrupt firms in relation to earnings predictability.

\section{CONCLUSIONS}

\section{Concluding Remarks}

The findings of this study bring several policy implications to Chinese regulators. The healthy firms are significantly different from bankrupt firms in relation to accruals quality, earnings predictability, and earnings smoothness, but not earnings persistence. Additional analysis reveals that financially distressed firms and bankrupt firms are significantly different in relation to two earnings attributes (earnings predictability and earnings smoothness), but not with accruals quality. Financially distressed firms are not significantly different from bankrupt firms in relation to earnings smoothness. Hence, a presumption that all earnings attributes behave significantly differently between healthy, financially distressed, and bankrupt firms should not be a foregone conclusion. The sample data also reveal that regardless of the firm category, Chinese-listed firms make negative earnings in any of the preceding 5 years.

Accruals quality is significantly different between healthy and bankrupt firms, and financially distressed and bankrupt firms, but it is not significantly different between healthy and financially distressed firms. Although further investigation is necessary, it may support Rosner's (2003) findings that financially distressed firms engage in earnings management to show earnings with high accruals quality. As accruals quality is closely related to cash-flow forecasts and firms' cost of capital, on that basis, it is possible that costs of capital of financially distressed firms are similar to those of healthy firms. Healthy and financially distressed firms significantly differ in relation to earnings smoothness, and this difference is not significant between financially distressed and bankrupt firms. These facts indicate to Chinese policy makers that financially distressed firms emulate some earnings quality attributes with healthy firms, and other earnings quality attributes with bankrupt firms, making it a grey area of firm classification. It is with caution that policy makers should make conclusions about the distinction of finan- cially distressed firms in relation to the four dimensions of accounting-based earnings quality. 
Accruals quality can affect cost of capital, because it is based on the accuracy of prediction of future cash flows, and similarity of accruals quality behavior between healthy and financially distressed firms means the cost of capital is unlikely to increase when the firm is financially distressed, but can significantly increase when the firm is in bankruptcy status. The earnings persistence in healthy firms is significantly different from that in financially distressed and bankrupt firms and is likely to sustain their earnings over a continuum. However, earnings volatility has an impact on earnings predictability; as healthy firms are significantly different from financially distressed and bankrupt firms; and bankrupt firms are significantly different from healthy firms and financially distressed firms. The private information included by managers in accruals to determine earnings variability to match with cash flows from operations variability, makes healthy firms different from financially distressed and bankrupt firms; and bankrupt firms different from healthy and financially distressed firms in relation to earnings smoothness quality. A future study investigating whether private information relates to managing earnings enhances earnings quality for the benefit of investors or managing earnings enhances earnings quality but to the detriment of investors, could assist policy makers to supplement the findings of this study.

The novelty of this research is that we classify firms as healthy, financially distressed, and bankrupt based on Altman (2006) EMS Z score criteria, and apply that classification to Chinese listed firms, where technically bankrupt firms (according to Western norms) are being listed on the Chinese stock exchanges, and investigate the differences of earnings quality attributes, contributing to earnings quality literature. In particular, this research is probably among the first several comprehensive studies to examine the listed firms of the largest emerging Chinese capital market.

\section{Limitations}

Our results are, however, subject to the following limitations. Because China is new to global economic activity, its economic system and business environment can have an impact on data availability and data quality. Due to the imperfect delisting system in China, we use the EMS model to classify firmyear observations as healthy, financially distressed, and bankrupt. Although the EMS model is tested in over 20 countries including China, the reliability of using the EMS model in China should be further identified with its changing economic and political landscape. 


\section{Future Research}

This article raises several questions for future research. First, future research could use a bankruptcy model that is industry specific to investigate the differences in industry characteristics on earnings quality attributes. Second, a future study could investigate research questions in this study with other proxies for earnings quality, such as the market-based attributes (value relevance, timeliness, and conservatism). Third, a future study could evaluate the influence of non-financial information on earnings quality attributes of Chinese-listed firms, which is currently sparsely explored. Fourth, a future study could consider earnings management in not-for-profit firms in China, a topic barely articulated as yet in the accounting literature.

\section{REFERENCES}

Aboody, D., Mary, E., \& Ron, K. (2004). Firms' voluntary recognition of stock-based compensation expense. Journal of Accounting Research, 42(2), 123-150.

Altman, E. I. (2006). Corporate financial distress and bankruptcy. Hoboken, NJ: John Wiley \& Sons.

Barker, R., \& Imam, S. (2008). Analysts' perceptions of earnings quality. Accounting and Business Research, 38(4), 313-329.

Basu, S. (1997). The conservatism principle and the asymmetric timeliness of earnings. Journal of Accounting and Economics, 24, 3-37.

Boonlert-U-Thai, K., Meek, G., \& Nabar, S. (2006). Earnings attributes and investorprotection: International evidence. International Journal of Accounting, 41, 327-357.

Bowen, R., Rajgopal, S., \& Venkatachalam, M. (2003, March 13). Accounting discretion, corporate governance and firm performance (Working paper). University of Washington and Duke University, Seattle WA and Durham North Carolina.

Buckmaster, D. (2001). In G. Previs and R. J. Bricker (Eds.), Studies in the development of accounting thought, Vol. 4. Development of the income smoothing literature 1893-1998: A Focus on the United States. Emerald Group Publishing Limited, Bingley, UK.

metric information. Journal of Corporate Finance: Contracting, Governance and Organization, 1, 319-345.

Dechow, M., \& Dichev, D. (2002). The quality of accruals and earnings: The role of accruals estimation errors. Accounting Review, 77 (Suppl), 35-59.

Dechow, M., \& Schrand, C. (2004). Earnings quality. Research Foundation of CFA Institute, New York, USA. 
Demski, J. (1998). Performance measure manipulation. Contemporary Accounting Research, 15, 261-285.

Dichev, I., \& Tang, V. (2009). Earnings volatility and earnings predictability. Journal of Accounting and Economics, 47 (1/2), 160-181.

Francis, J., LaFond, R., Olsson, P., \& Schipper, K. (2004). Costs of equity and earnings attributes. Accounting Review, 79, 967-1010.

Francis, J., LaFond, R., Olsson, P., \& Schipper, K. (2005). The market pricing of accruals quality. Journal of Accounting and Economics, 39, 295-327.

Francis, J., Olsson, P., \& Schipper, K. (2008). Earnings quality. Foundations and Trends in Accounting, 1(4), 259-340.

Hayn, C. (1995). The information content of losses. Journal of Accounting and Economics, 20, 125-153.

Kormendi, R., \& Lipe, R. (1987). Earnings innovations, earnings persistence, and stock returns. Journal of Business, 60, 323-345.

Leuz, C., Nanda, D., \& Wysocki, P. (2003). Earnings management and investor protection: An international comparison. Journal of Financial Economics, 69, 505-527.

Lipe, R. (1990). The relation between stock returns and accounting earnings given alternative information. Accounting Review, 65, 49-71.

Lu, Q., \& Liu, Z. (2007). Corporate governance and Earnings management in the Chinese listed companies: A tunneling perspective. Journal of Corporate Finance, 13, 881-906.

McKeown, J., Mutchter, J., \& Hopwood, W. (1991). Towards an explanation of auditor failure to modify the audit opinion of bankrupt companies. Auditing: $A$ Journal of Practice and Theory, 10(Supplement), 1-13.

McNichols, M. (2002). Discussion of the quality of accruals and earnings: The role of accruals estimation error. Accounting Review, 77 (Suppl), 61-69.

Nichols, D. C., \& Wahlen, J. M. (2004). How do earnings numbers relate to stock returns? A review of classic accounting research with updated evidence. Accounting Horizons, 18(4), 263-286.

Penman, S., \& Zhang, X. J. (2002). Accounting conservatism, the quality of earnings, and stock returns. Accounting Review, 77, 237-264.

Qi, D., Wu, D., \& Wu, W. (2005). Market consequences of earnings management in response to security regulations in China. Contemporary Accounting Research, 22(1), 95-140.

Richardson, S. (2003). Earnings quality and short sellers. Accounting Horizons, 17 , 49-61.

Ronen, J., \& Sadan, S. (1981). Smoothing income numbers: Objective, means and implications, MA: Addison Wesley, Boston, USA.

Ronen, J., \& Yaari, V. (2008). Earnings management - Emerging insights in theory, practice, and research. Springer Science+Business Media LLC, Philadelphia, USA.

Rosner, R. (2003). Earnings manipulation in failing firms. Contemporary Accounting Research, 20(2), 361-408.

Schipper, K., \& Vincent, L. (2003). Earnings quality. Accounting Horizons, 17, $97-$ 111. Sloan, R. (1996). Do stock prices fully reflect information in accruals and cash flows

about future earnings? Accounting Review, 71(3), 289-315.

Wysocki, P. D. (2004). Discussion of ultimate ownership, income management, and legal and extra-legal institutions. Journal of Accounting Research, 42, 463-474. 


\section{APPENDIX A}

Panel Data Regression Results for Earnings Quality Attributes for Healthy Versus Financially Distressed Firms

\begin{tabular}{lcccccccc}
\hline & $\begin{array}{c}\text { AQ } \\
\text { Coefficient }\end{array}$ & $\begin{array}{c}\text { AQ } \\
\text { Prob. Coefficient }\end{array}$ & $\begin{array}{c}\text { PRED } \\
\text { Prob. }\end{array}$ & $\begin{array}{c}\text { PRED } \\
\text { Coefficient }\end{array}$ & $\begin{array}{c}\text { PERS } \\
\text { Prob. }\end{array}$ & $\begin{array}{c}\text { SMOOTH } \\
\text { Coefficient }\end{array}$ & $\begin{array}{c}\text { SMOOTH } \\
\text { Prob. }\end{array}$ \\
\hline H versus FD & 0.011 & 0.457 & $-0.042^{* *}$ & 0.010 & $0.184^{* * *}$ & 0.000 & -0.082 & 0.004 \\
OPCYCL & -0.015 & 0.200 & 0.018 & 0.545 & -0.009 & 0.824 & -0.004 & 0.887 \\
NEGEARN & $0.066^{* * *}$ & 0.000 & -0.008 & 0.543 & $-0.085^{*}$ & 0.083 & 0.087 & 0.003 \\
CFO & $0.140^{* *}$ & 0.021 & $0.247^{* *}$ & 0.015 & -0.124 & 0.745 & 0.563 & 0.000 \\
SALES & 0.006 & 0.765 & 0.028 & 0.328 & -0.044 & 0.736 & -0.036 & 0.402 \\
SIZE & -0.024 & 0.261 & $-0.126^{* * *}$ & 0.000 & $0.217^{* * *}$ & 0.000 & -0.133 & 0.015 \\
Constant & 0.278 & 0.188 & $1.273^{* * *}$ & 0.000 & $-1.644^{* * *}$ & 0.005 & $1.497^{* * *}$ & 0.004 \\
Adjusted R $R^{2}$ & 0.07 & & 0.04 & & 0.09 & & 0.06 & 2,715 \\
Observation & 2,715 & & 2,715 & & 2,715 & & 2,004 & \\
\hline
\end{tabular}

Sample of 2,715 firm-year observations consists of 1,046 healthy firm-years and 1,669 financial distressed firm-years; $\mathrm{AQ}=$ Accrual quality; PRED = Earnings predictability; PERS = Earnings persistence; $\mathrm{SMOOTH}=$ Earnings smoothness; $\mathrm{H}$ versus $\mathrm{FD}=$ Healthy versus financial distressed firm dummy; $\mathrm{CFO}=\mathrm{Standard}$ deviation of cash flows scaled by assets; SALES $=$ Standard deviation of sales revenue scaled by assets; SIZE $=$ Log of total assets; OPCYCL $=$ Log of operating cycle length; NEGEARN = Negative earnings dummy.

*Significant at better than the $10 \%$ level, ${ }^{* *}$ Significant at better than the $5 \%$ level, ${ }^{* * *}$ Significant at better than the $1 \%$ level.

\section{APPENDIX B}

Panel Data Regression Results for Earnings Quality Attributes for Financially Distressed Versus Bankrupt Firms

\begin{tabular}{lcccccccc}
\hline & $\begin{array}{c}\text { AQ } \\
\text { Coefficient }\end{array}$ & $\begin{array}{c}\text { AQ } \\
\text { Prob. Coefficient }\end{array}$ & $\begin{array}{c}\text { PRED } \\
\text { Prob. }\end{array}$ & $\begin{array}{c}\text { PRED } \\
\text { Coefficient }\end{array}$ & $\begin{array}{c}\text { PERS } \\
\text { Prob. }\end{array}$ & $\begin{array}{c}\text { SMOOTH } \\
\text { Coefficient }\end{array}$ & $\begin{array}{c}\text { SMOOTH } \\
\text { Prob. }\end{array}$ \\
\hline FD versus B & $-0.079^{* *}$ & 0.011 & $-0.093^{* * *}$ & 0.001 & $-0.121^{*}$ & 0.099 & -0.068 & 0.127 \\
OPCYCL & $-0.056^{* * *}$ & 0.003 & 0.029 & 0.376 & 0.001 & 0.981 & -0.131 & 0.212 \\
CFO & $0.161^{* * *}$ & 0.005 & $0.266^{* * *}$ & 0.004 & -0.061 & 0.853 & $0.514^{* * *}$ & 0.000 \\
SALES & 0.018 & 0.339 & 0.024 & 0.323 & -0.080 & 0.384 & -0.015 & 0.759 \\
SIZE & -0.012 & 0.659 & $-0.197^{* * *}$ & 0.000 & $0.234^{* * *}$ & 0.000 & $-0.167^{* *}$ & 0.017 \\
Constant & $0.453^{*}$ & 0.083 & $2.087^{* * *}$ & 0.000 & $-1.648^{* * *}$ & 0.001 & $2.228^{* * *}$ & 0.000 \\
Adjusted R ${ }^{2}$ & 0.03 & & 0.09 & & 0.11 & & 0.05 & 1,915 \\
Observation & 1,915 & & 1,915 & & 1,915 & & 1,915 & \\
\hline
\end{tabular}

Sample of 1,915 firm-year observations consists of 1,669 financial distressed firm-years and 246 bankrupt firm-years, $\mathrm{AQ}=$ Accrual quality; PRED = Earnings predictability; PERS = Earnings persistence; $\mathrm{SMOOTH}=$ Earnings smoothness; FD versus $\mathrm{H}=$ Financial distressed versus bankrupt firm dummy; $\mathrm{CFO}=$ Standard deviation of cash flows scaled by assets; SALES = Standard deviation of sales revenue scaled by assets; SIZE = Log of total assets; OPCYCL=Log of operating cycle length; NEGEARN $=$ Negative earnings dummy.

*Significant at better than the $10 \%$ level, ${ }^{* *}$ Significant at better than the $5 \%$ level, ${ }^{* * *}$ Significant at better than the $1 \%$ level. 